\title{
THE ENTRENCHMENT STRATEGY OF LOGISTICS SERVICE PROVIDERS: TOWARDS A SEQUENTIAL COOPERATION-COMPETITION PROCESS?
}

\author{
GILLES PACHÉ \\ gilles.pache@univmed.fr \\ Université de la Méditerranée (Aix-Marseille II), France \\ PABLO MEDINA \\ pablojaime.medina@cemex.com \\ Cemex, Mexico
}

\begin{abstract}
The logistics industry has been attracting the attention of researchers in management for several years. Their focus is increasingly on interorganisational relationships between logistics service providers and their customers, examining the modes of interaction occurring between them. An abundant literature emphasises the importance of cooperative strategies in the logistics industry, hinting that this is a dominant requirement, destined for inevitable development. This article presents a more qualified position and proposes that cooperative strategies are most likely a transition step between arm's-length competition periods, and resorts to the entrenchment theory, imported from organisational finance, to propose a sequential cooperation-competition model.
\end{abstract}

\section{INTRODUCTION}

The phenomenon of logistics outsourcing is nowadays a major field of investigation in supply chain management, and also in strategic management and organisation theory. It is true that the inclusion of powerful logistics service providers (LSPs) has strengthened some existing models, but in some cases, it has also raised doubts about their efficacy. In its glossary of logistics terms published in October 2005, the French journal Logistiques Magazine gives a general but adequate definition of a LSP: "a firm ensuring the performance of logistics activities on behalf of a manufacturer or a large retailer". However, there immediately follows three LSP families, defined by the complexity of their service offer and not on their strategic position in supply chains:

- conventional LSPs, which simply execute physical operations related to transport, handling and storage of customers' work-in-process components or finished goods along a supply chain;

- value-added LSPs, which additionally include the management of manufacturing operations (e.g. some postponement activities), administrative operations (e.g. invoicing) and information operations (e.g. tracing and tracking); and

- dematerialised LSPs, which own almost no physical resources, but build a customised service offering for their customers by involving the resources from different partners. 
Understanding the evolution of the logistics industry usually requires adopting two levels of analysis at the same time. One is to assess the role and impact of outsourcing in the optimisation of logistical and supply chain processes (supply side), and the other, to study the evolution of activities offered by LSPs (demand side). This article reviews the second perspective only, by questioning the pertinence and issues of strategies implemented today by European LSPs towards their customers, manufacturing or retailing firms. The strategic intelligence of some LSPs lies in having anticipated and then satisfied their customers' new logistics (and supply chain) needs. To simplify, three historical steps are identifiable: (1) manufacturers (or large retailers) acquire a given logistical component (product transport, warehousing facilities, etc.); LSPs are at this stage considered to be mere performers of operations without any control of design; (2) manufacturers (or large retailers) wish to buy complete logistical functions, for example the comprehensive management of physical and information flows, from a factory down to an outlet network; LSPs propose innovative technical solutions to optimise the supply chain; (3) manufacturers (or large retailers) decide to outsource high value-added activities such as assembly, packaging postponement or customer-specific label printing, to focus as a priority on product or service development.

The third stage explains why, in the past few years, an increasing number of LSPs have tried to negotiate partnership agreements with their major customers. They usually wish for longterm cooperative strategies based on investments in specific assets, requiring only occasional association with customers, and a strong interdependence in monitoring supply chains (Paché \& Sauvage, 2004). One of the best examples of this is the construction of a dedicated warehouse of more than $100,000 \mathrm{~m}^{2}$ by Norbert Dentressangle, on the southern outskirts of Paris, to manage the whole clothing supply chain for Carrefour. The warehouse was situated and fully equipped to satisfy the sole needs of Carrefour, following a long period of maturation during which Norbert Dentressangle and Carrefour teams interacted constantly to materialise the project. Many observers note that this strategy should lead to a significant improvement in the performance of relationships, compared to the spot contracts frequently used in the logistics industry.

The purpose of the article is to determine whether cooperative strategies can last, by resorting to a type of analysis used in organisational finance, i.e. the management entrenchment theory. The major proposition is that LSPs should try to develop and strengthen relationships with a customer to increase performance. At first, entrenchment presents positive aspects for both parties, before deteriorating into a constant battle of wills causing the cooperative strategy to transform to arm's-length competition. Therefore while there are cooperative and competitive elements in LSP-customer relationships, this needs to be described in a sequential model where cooperation and competition follow each other rather than occur simultaneously as suggested by the Bengtsson and Kock (2000) research. The original model refers to the main results of a case study conducted by Medina (2006) on the French logistics industry. 


\section{THE MANAGEMENT ENTRENCHMENT THEORY: APPLICATION TO LOGISTICAL RELATIONSHIPS}

With its promise of promoting knowledge in management, the management entrenchment theory tries to explain the reasons and the means through which companies' top managers succeed in staying in their positions, sometimes against shareholders' wishes, and that induce them to understand that their presence is absolutely necessary, even when their financial performance is poor (Paquerot, 1997). In brief, "the process of management entrenchment is expressed by strategies implemented by top managers to make themselves indispensable and difficult to oust" (Allemand, 2006: 42). Management entrenchment results from the fact that, for shareholders, the cost of replacing a top manager is thought to be greater than the cost of keeping the manager place (Carroll \& Griffith, 2002). Following Berger, Ofek and Yermack (1997) and Allemand (2006), we define management entrenchment as a progressive process in which top managers succeed in staying in their jobs in spite of company governance aimed at maximising financial performance and despite competition in the market for top managers.

Just as top managers try to cling to their positions, companies involved in relationships with other firms may also have the objective of maintaining those relationships so as to continue benefiting from associated advantages, such as profiting from captive customers who are impervious to variations in the quality of products or services offered. Applying the management entrenchment theory reasoning to relationships governing a top manager and a firm to relationships between two firms is not surprising if one considers that top managers make decisions on behalf of the firms employing them. In his research on managers' daily tasks, Mintzberg (1973) showed that decisions are made by individuals who often have their own motives for their decisions. Their daily work is therefore essentially determined by the requirements of their firms as well as solicitations outside that environment. Those solicitations often shape the behaviour of top managers in strategic management of relationships. To speak of a firm's wish for entrenchment in a relationship means that it is, in fact, top management that finds a specific interest and the means of achieving its objective.

Gundlach and Cadotte (1994), Lusch and Brown (1996), and Maloni and Benton (2000), state that the performance of a relationship increases when interdependence between firms becomes strong and symmetrical. This situation is explained by the shared interest in cooperating to find means for creating value or for reducing given costs, by sharing equally the benefits that may be generated by the relationship (Lusch \& Brown, 1996). According to Heide (1994), symmetrical interdependence promotes the alignment of the parties' interests, favours flexibility and discourages opportunistic behaviours, thus allowing the relationship to flourish. Paché (2002) adds that a state of coordination in the relationship is characterised by an asymmetrical ratio between powers, while a state of cooperation may 
only arise from a symmetrical power configuration. To sum up, a firm trying to consolidate its relationship with another must look at the balance of power to make the most of the relationship.

Traditionally, power corresponds to the ability of a company to act on the perception of its business partner so as to influence the partner's attitudes, behaviour and decisions to achieve the objectives that the company defined for the relationship. Thus, the power of a given firm results from convergent factors: (1) the degree of difficulty for the partner of finding another partner, either because of the benefits it brings or for technical reasons; and (2) the efficiency of the implementation of power sources. It seems promising to apply the management entrenchment theory to the context of exchanges between LSPs and their customers to explain situations of long-term logistical relationships, but also of changes from cooperation to arm's-length competition.

The suggested sequential model is based on two assumptions. LSPs initiate the idea that the relationship should last to increase their own benefits. However, customers must also see that there is an advantage in this for them. A good execution of operations by LSPs and increased cooperation with their customers are essential for the success of the process. In addition, the relationship between customers and LSPs may be considered as an agency relationship (Sauvage, 1997; Chanson, 2003), since the customer (principal) appoints an LSP as its representative (agent) and delegates the performance of logistical activities. This relationship brings to the fore the three issues that need to be addressed in an agency relationship: (1) there are conflicting objectives between the agent and the principal generating opportunistic behaviours; (2) there is a high level of uncertainty about the principal's income, particularly about sharing the created value and about the continuity of the relationship; and (3) it is difficult to assess the principal's behaviour and performance, particularly if there is a possibility of information asymmetries (Eisenhardt, 1989).

On the basis of research conducted on the strategies of French LSPs, the authors propose a three-stage model of evolution explaining why a strategy of cooperation between LSPs and their customers may progressively switch to a strategy of arm's-length competition. The transition from cooperation to competition does not prevent LSPs from entrenching a relationship and taking advantage of their expert power to make their customers dependent on them. In other words, value creation increasingly benefits LSPs who know how to profit from the original stage of cooperation. Before explaining the three identified stages, let us point out that the level of entrenchment of a logistical relationship is measured by the degree of difficulties met by firms to bring it to an end. Such difficulties may arise from the benefits the relationship provides or from the appropriation of gains by the firm adopting an opportunistic approach. 


\section{LOOKING FOR VALUE CREATION IN THE RELATIONSHIP}

The agency relationship that this article analyses starts when a relationship is established between partners, a seller and a buyer of logistical services, with or without a written contract. In both cases, the manufacturer's or the large retailer's top management selects an LSP from among the different operators in the market of logistical services, and they perceive that it would be easy to change LSPs, since there is an excess on offer. Consequently, the balance of power leans towards the manufacturer or large retailer instigating the logistical relationship. The customer's power is based on its low dependency on the LSP, because the customer initiated the relationship and selected one LSP from among many others, often after a call for bids. The customer also uses its reputation in the market for producing or distributing goods to strengthen its power during negotiations.

In this first stage, preceding the implementation of a cooperative strategy, the LSP very quickly perceives the usefulness of the relationship for improving its own reputation in the market for logistical services; this reputation will serve to achieve its objective of extending its customer portfolio. The LSP's reputation may rely, among other factors, on the diversity of services offered, the use of new information and communication systems for tracking and tracing (Roussat \& Fabbe-Costes, 2000), awards given by professional associations, or the granting of quality standards such as ISO 9000 (Logan, 2000). It should be noted that, according to various works conducted on logistical outsourcing procedures, industrial firms increasingly select LSPs on a perception of their performance and ability to adapt, before examining the price of the services offered (Paché \& Sauvage, 2004).

If an LSP performs outsourced activities appropriately and if the relationship achieves the objectives determined by the customer, the customer has a more positive perception of the relationship and increasingly values it; in other words, customers consider that a relationship is a source of value if the resulting performance is maintained or increases (Moore \& Cunningham, 1999). If the LSP wishes to continue receiving benefits through its management of outsourced activities, it must demonstrate to its customer that it is able to offer it a much greater value than its competitors in the market for logistical services, i.e. that it is the only one able to offer a sustainable competitive advantage. The customer's dependency towards the LSP grows as value creation increases because of the LSP's performance.

During the first stage of the relationship, the customer has to make specific choices on how to share the value created and over the degree of freedom of action left to the LSP in conducting outsourced activities. If the customer decides to take advantage of a now favourable situation of power asymmetry to maximise its own profit by capturing the greater part of the created value, it runs the risk of displeasing the LSP. This dissatisfaction may reduce the efficiency of the relationship and the LSP may distrust its customer and, for 
example, restrain its innovative efforts to improve the execution of outsourced activities. If, in contrast, the customer accepts a fair share of the created value in view of the LSP's willingness, it will encourage the LSP's increasing commitment to and trust in the relationship; interdependence between both firms will be strengthened.

If a customer reduces its LSP's degree of autonomy, for fear of losing the control of outsourced activities and of the LSP's opportunistic behaviours, it runs the risk of irreparably damaging the relationship. This is the case when customers use the sources of power at their disposal (awards and penalties) to signify to LSPs that they must do what their customers require. In academic literature, resorting to a unilateral use of power will probably have a negative effect on the performance level of the relationship (Skinner, Gassenheimer \& Kelley, 1992; Brown, Lusch \& Nicholson, 1995; Kumar, Scheer \& Steenkamp, 1998). Inversely, if customers leave some discretionary freedom to LSPs, it might motivate suggestions for innovative logistical solutions to increase their customers' capacity for adaptation and flexibility, even if LSPs have to invest in specific assets. Decisions made by customers during the first stage are the determining factors that will either orientate the relationship towards a cooperative strategy, or let it deteriorate into an arm's-length competition strategy. If decisions aim exclusively at increasing the power of customers, they break the equal balance of power, essential for the next stage of positive entrenchment.

\section{POSITIVE ENTRENCHMENT, OR THE TRIUMPH OF COOPERATION}

The most efficient way of creating value in interorganisational relationships is to maintain and develop a strong and symmetrical interdependence between firms (Gundlach \& Cadotte, 1994; Lusch \& Brown, 1996; Coughlan, Anderson, Stern \& El-Ansary, 2006). This interdependence promotes the emergence of an atmosphere of commitment and trust within the top management teams of partners involved in a relationship. Coupled to the symmetry of powers, interdependence encourages firms to implement a cooperative strategy more easily, and not to show opportunism when that is possible. Within logistical relationships between LSPs and their customers enjoying such a climate of commitment and trust, the customers are more willing to anticipate conflicts, or to solve them in a constructive way when they are unavoidable, by making the same efforts as those made by their partners.

The main reason leading LSPs to consolidate their relationships with customers is the possibility of a high level of performance generated by obtaining more financial and nonfinancial benefits through the value created on both sides. LSPs are encouraged to take the most suitable steps to achieve a good balance of power - unequal in the first stage of the relationship - and to establish a strong and symmetrical interdependence with their customers. Thus LSPs will endeavour to implement strategies leading to entrenchment in the relationship. How is that done in practice? LSPs present themselves as essential partners, whose level of competence and expertise is such that they become indispensable to customers if customers want to increase the efficiency of their supply chain. 
At this stage, we may draw the first conclusion that the performance of the relationship will improve depending on the level of entrenchment of LSPs. However, because the LSPs wish to perpetuate the relationship, it is highly likely that they will want to supervise the process themselves, by directly and fully designing logistical solutions, and will not content themselves with carrying out logistical operations under the customer's supervision (Tixier, Mathe \& Colin, 1983). If achieving a situation of symmetry of powers is essential in this approach, it may be expected that customers, to protect their own interests, will try to maintain a balance of power in their favour, while encouraging a high interdependence with LSPs. Table 1 presents the objectives of the three strategies of positive entrenchment most commonly used by LSPs' top management, as defined in Medina's (2006) case study.

Table 1: Entrenchment strategies currently applied by LSPs' top management within the logistical relationship

\begin{tabular}{|c|c|c|c|}
\hline $\begin{array}{l}\text { Entrenchment } \\
\text { strategies }\end{array}$ & Objectives & $\begin{array}{l}\text { Means of } \\
\text { application }\end{array}$ & Benefits \\
\hline $\begin{array}{l}\text { Investment in } \\
\text { specific assets }\end{array}$ & $\begin{array}{l}\text { Increase and } \\
\text { balance firms' } \\
\text { inter-dependence }\end{array}$ & $\begin{array}{l}\text { Use of specific } \\
\text { assets* }\end{array}$ & $\begin{array}{l}\text { - Facilitates value creation as } \\
\text { it can improve the efficiency } \\
\text { of outsourced activities and } \\
\text { encourage the emergence } \\
\text { of a sustainable competitive } \\
\text { advantage (Ghosh \& John, } \\
\text { 1999) } \\
\text { - Facilitates development of } \\
\text { relationship from spot } \\
\text { exchanges to a cooperative } \\
\text { strategy, and partners' } \\
\text { commitment (Yemisi, 2001) }\end{array}$ \\
\hline Informational & $\begin{array}{l}\text { Increase LSPs' } \\
\text { power }\end{array}$ & $\begin{array}{l}\text { Total transparency } \\
\text { in the definition of } \\
\text { objectives and } \\
\text { expectations of } \\
\text { parties } \\
\text { Exchange of } \\
\text { information on the } \\
\text { relationship's } \\
\text { environment } \\
\text { Public recognition } \\
\text { of customers' } \\
\text { good behavioural } \\
\text { reputation }\end{array}$ & $\begin{array}{l}\text { - Facilitates reduction of } \\
\text { divergences between firms, } \\
\text { by encouraging commitment } \\
\text { and trust among LSPs' top } \\
\text { management (Moore, 1998) } \\
\text { - Facilitates LSP's commitment, } \\
\text { helping it to be receptive and } \\
\text { reactive, and potentially to } \\
\text { adapt the relationship to } \\
\text { external constraints (Murphy } \\
\text { \& Poist, 2000) } \\
\text { - Facilitates employees' trust } \\
\text { in and commitment to } \\
\text { partner (Boyle \& Dwyer, } \\
\text { 1995) }\end{array}$ \\
\hline $\begin{array}{l}\text { Negotiated } \\
\text { sharing of } \\
\text { value created }\end{array}$ & $\begin{array}{l}\text { Extend LSPs' power } \\
\text { by strengthening } \\
\text { inter-dependence } \\
\text { with customers }\end{array}$ & $\begin{array}{l}\text { Fair sharing of gains } \\
\text { associated with } \\
\text { investments in } \\
\text { specific assets made } \\
\text { by LSPs }\end{array}$ & $\begin{array}{l}\text { - Encourages LSP to innovate } \\
\text { and take greater risks (Logan, } \\
\text { 2000) }\end{array}$ \\
\hline
\end{tabular}

*A specific asset is an investment to supply a tailored service, the maximum value of which corresponds to its use within the relationship only. 
The implementation of a strategy of investment in specific assets modifies the balance of power and above all increases interdependence between LSPs and their customers. However, although investing in such assets increases interdependence within the relationship, it also increases the risk for the investing LSP and/or the customer of being forced to accept its partner's opportunistic behaviours (Rokkan, Heide \& Wathne, 2003). To increase their interdependence, it is therefore desirable that the LSP and its customer invest in specific assets equally, which will facilitate value creation in the long term. They will then be able to overcome the risk of the other's domination and minimise opportunistic temptations (Lonsdale, 2001). In addition, the LSP and its customer will be more willing to solve conflicts because bringing the relationship to an end would result in sunk costs for both, the direct consequence of a loss of value of the specific assets outside the relationship. Thus, the second stage leads to the formalisation of cooperative strategies facilitating the successful execution of logistical activities and achieving the objectives of the relationship.

Through the implementation of an informational strategy, the LSP aims at increasing its power by showing its customer that it has accumulated major expertise (better management of the supply chain, capacity to innovate in new logistical services). Thanks to its entrenchment strategy, the LSP consolidates its power over its customer, but it is also likely to observe a positive effect on its own level of satisfaction with the relationship; it encourages its customer to use the same sources of power as itself, particularly expert power (Johnson, Sakano, Cote \& Onzo, 1993). Commitment and trust are therefore reinforced and promote a climate for a flourishing long-term cooperative strategy. Logistical activities performed well by LSPs, combined with customer satisfaction, tend to improve the relationship performance and to augur well for its sustainability (Mayo, Richardson \& Simpson, 1998).

Finally, by implementing a strategy of negotiated sharing of created value, the LSP also increases its power over its customer, but this greatly strengthens their interdependence. This strategy helps preclude any conflict by recommending an equal distribution of the gains from the LSP's investments in specific assets. The discussion over the sharing of benefits is based on the added value produced by the relationship thanks to the LSP's competencies and expertise, but mainly thanks to the cooperative strategy produced by collaborative work between the LSP and its customer (Cox, 2001). The second stage of the sequential model is characterised by increased interdependence since both LSPs and customers perceive that the system is fair and helps them obtain greater benefits than those obtained during the first stage of the relationship.

When the entrenchment strategies started by LSPs become successful, the LSPs' expert power significantly increases, snowballing into an increased interdependence between LSPs and their customers. However, it is very likely that the customers themselves set their own 
objectives. It is to be expected that they develop a sort of "countervailing power", in Galbraith's (1952) terms, to maximise the benefits of the relationship. Finally, with more interdependence between LSPs and customers, and the development of a countervailing power on the part of the customers, the relationship results in a situation of power symmetry; hence the idea of positive entrenchment as a manifestation of cooperative strategy. However, Medina's (2006) case study highlights another stage that sometimes leads LSPs to take too much advantage of the situation to capture most of the created value, thus programming the end of the cooperative strategy.

\section{DEEPLY ROOTED ENTRENCHMENT, OR THE SCHEDULED END OF THE RELATIONSHIP}

The symmetry of powers and increased interdependence in the relationship are the consequences of actions taken by LSPs' top management, but also by customers' top management. However, the LSP approach - implementing three types of entrenchment strategies (see Table 1) - does not guarantee a lasting improvement in the relationship performance for two essential reasons. LSP entrenchment strategies may have, over time, amplified effects that can generate a situation of asymmetry in interdependence. In addition, customers may increase their power by making LSPs aware that investment in specific assets completely locks up the LSPs inside the relationship; they are therefore at the customers' mercy during the renegotiation of the outsourcing contract. Baudry (2006) describes this situation to perfection.

When both phenomena occur simultaneously it leads to a deterioration of the relationship's political economy, according to Stern and Reve (1980), and this is likely to reduce performance and consequently the added value created. According to Moore and Cunningham (1999), the intensity of the commitment and trust felt by LSP top management varies, positively or negatively, depending on its perception of the level of performance achieved by the relationship. It is likely that a deterioration in the level of performance will cause an uncontrollable chain of conflicts. For example, as mentioned above, investment in specific assets financed by LSPs and their customers, may result in a situation of captivity for LSPs if customers mention that they would like to end the relationship early on. LSP top management will then feel all the more captive as the other entrenchment strategies will have failed.

However, a completely different scenario plays out if the LSP succeeds in acquiring essential skills that are impossible to imitate. In this case, the customer is forced to accept the execution of logistical activities by the LSP even if poor, to avoid the financial losses that a possible end of the relationship would cause. The customer then tries to modify the existing specifications or to use rival LSPs to influence their current LSP's behaviour. These measures 
are obviously perceived by both the LSP and customer as the result of an unavoidable deterioration of the climate of trust. Both will question the pertinence of maintaining a cooperative strategy. Even if the relationship still creates added value for the LSP and its customer, the level of performance starts to stagnate, or even deteriorate. The relationship enters a third stage, that of deeply rooted entrenchment.

What does this really mean? Undoubtedly the relationship has passed its ideal level of entrenchment, where the creation of value was at its greatest for both the customer and LSP. The deterioration of the relationship reaches a new stage, again characterised by an asymmetry of powers. The LSP now considers its customer as an opponent from whom the aim is to get the most profit in the shortest period. If partners do not react immediately by reviewing the reasons for their relationship floundering, it is likely that this relationship will break off. Exchanges will then be re-established, based on competition and more broadly on a climate of suspicion and lack of transparency. Medina's (2006) case study describes several cases of this type of situation, marked by a premature end of cooperative strategies between LSPs and their customers in the agri-food supply chain context.

Deeply rooted entrenchment does not inevitably result in arm's-length competition, where sharing added value becomes an acrimonious issue, although all the conditions for this to occur are in place. LSPs have progressively acquired expertise enabling them to impose their will on customers who are fully aware that they have a substantial amount to lose if the relationship is broken off. As a result, customers anticipate - at the beginning of the second stage - the threat of a lock-in, which will limit their freedom of action. It is to be expected then that customers quickly - implicitly or explicitly - plan to get out of a relationship based on a cooperative strategy, even if they have to bear a part of sunk costs. Presuming that this is the case, the process of cooperation and competition should be studied not simultaneously but sequentially, with any cooperation between LSPs and their customers systematically containing the germs of competition as the ultimate stage in their relationship. The debate is obviously open in terms of assessing the impact of this heterodox approach on a systematically doomed cooperative strategy.

\section{CONCLUSION}

The number of manufacturing and retailing firms that no longer wish to manage their logistical activities themselves has been constantly increasing in Europe and in North America (Paché \& Sauvage, 2004). The reasons are well known: they must restructure their overall supply chains to improve operational coordination, face up to fluctuations in product volumes and destinations, reduce costs and increase service quality in terms of flexibility, deadlines and product customisation, while adapting to the internationalisation of markets. The LSPs' service offerings followed and in some cases anticipated this new demand in three 
complementary directions: (1) reorganisation by sectors and customers at European level; (2) collaboration with consultancies specialised in monitoring tool management; (3) development of original procedures to ensure the perfect traceability of flows in cooperation with customers.

This article has approached the question of the interorganisational relationship between LSPs and their customers by adopting an original conceptual frame, to draw the conclusion that cooperative strategies seem to be only a transitional period between two stages favouring arm's-length competition. Of course, this sequential vision of cooperationcompetition is but a beginning that will require further investigation to decide on its pertinence. It seems important to understand why a cooperative strategy is likely to weaken and die in some cases and not in others. A complete work of contextualisation remains to be done, at the risk of remaining at a too general level of analysis. Beyond their intrinsic interest for promoting knowledge in management, answers should interest top managers, particularly for understanding the failure of some partnership agreements within supply chains - that are yet unexplained. 
The Entrenchment Strategy of Logistics Service Providers: Towards a Sequential Cooperation-competition Process?

\section{REFERENCES}

Allemand, I. 2006. Le rôle du marché des dirigeants dans le système de gouvernance des entreprises: une revue de la litérature. Gestion, 23(3): 21-58.

Baudry, B. 2006. L'économie des relations interentreprises. Paris: La Découverte.

Bengtsson, M. \& Kock, S. 2000. Coopetition in business networks - To cooperate and compete simultaneously. Industrial Marketing Management, 29(5): 411-426.

Berger, P., Ofek, E. \& Yermack, D. 1997. Managerial entrenchment and capital structure decisions. Journal of Finance, 52(4): 1411-1438.

Boyle, B. \& Dwyer, R. 1995. Power, bureaucracy, influence, and performance: their relationships in industrial distribution channels. Journal of Business Research, 32(1): 189-200.

Brown, J., Lusch, R. \& Nicholson, C. 1995. Power and relationship commitment: their impact on marketing channel member performance. Journal of Retailing, 71(4): 363-392.

Carroll, C. \& Griffith, J. 2002. Management retention following poor performance: board failure or management entrenchment. Working Paper No. 02-02-03, University of Alabama, Tuscaloosa, AL.

Chanson, G. 2003. Externalisation et performance dans la relation client-prestataire. Revue Française de Gestion, 143: 43-54.

Coughlan, A., Anderson, E., Stern, L. \& El-Ansary, A. 2006. Marketing channels. Upper Saddle River, NJ: Pearson Prentice-Hall, $7^{\text {th }}$ ed.

Cox, A. 2001. Managing with power: strategies for improving value appropriation from supply relationships. Journal of Supply Chain Management, 37(2): 42-46.

Eisenhardt, K. 1989. Agency theory: an assessment and review. Academy of Management Review, 14(1): 57-74.

Galbraith, J.-K. 1952. American capitalism: the concept of countervailing power. Boston, MA: Houghton Mifflin.

Ghosh, M. \& John, G. 1999. Governance value analysis and marketing strategy. Journal of Marketing, 63(Special Issue): 131-145. 
Gundlach, G. \& Cadotte, E. 1994. Exchange interdependence and interfirm interaction: research in a simulated channel setting. Journal of Marketing Research, 31(4): 516-532.

Heide, J. 1994. Interorganizational governance in marketing channels. Journal of Marketing, 58(1): 71-85.

Johnson, J., Sakano, T., Cote, J. \& Onzo, N. 1993. The exercise of interfirm power and its repercussions in US-Japanese channel relationships. Journal of Marketing, 57(2): 1-10.

Kumar, N., Scheer, L. \& Steenkamp, J. 1998. Interdependence, punitive capability, and the reciprocation of punitive actions in channel relationships. Journal of Marketing Research, 35(2): 225-235.

Logan, M. 2000. Using agency theory to design successful outsourcing relationships. International Journal of Logistics Management, 11(2): 21-32.

Lonsdale, C. 2001. Locked-in to supplier dominance: on the dangers of asset specificity for the outsourcing decision. Journal of Supply Chain Management, 37(2): 22-27.

Lusch, R. \& Brown, J. 1996. Interdependency, contracting, and relation behavior in marketing channels. Journal of Marketing, 60(4): 19-38.

Maloni, M. \& Benton, W. 2000. Power influences in the supply chain. Journal of Business Logistics, 21(1): 49-73.

Mayo, D., Richardson, L. \& Simpson, J. 1998. The differential effects of the uses of power sources and influences strategies on channel satisfaction. Journal of Marketing Theory and Practice, 27(2): 16-24.

Medina, P. 2006. La pérennisation de la relation entre le chargeur et son prestataire logistique. Une explication par la contextualisation de l'enracinement. Thèse de doctorat en Sciences de Gestion, Université de la Méditerranée (Aix-Marseille II).

Mintzberg, H. 1973. The nature of managerial work. New York, NY: Harper \& Row.

Moore, K. 1998. Trust and relationship commitment in logistics alliances: a buyer perspective. International Journal of Purchasing \& Materials Management, 38(1): 24-37.

Moore, K. \& Cunningham, W. 1999. Social exchange behavior in logistics relationships: a shipper perspective. International Journal of Physical Distribution \& Logistics Management, 29(2): 103-121. 
Murphy, P. \& Poist, R. 2000. Third-party logistics: some user versus provider perspectives. Journal of Business Logistics, 21(1): 121-133.

Paché, G. 2002. L'évolution des relations logistiques entre industriels et détaillants: coopération ou simple coordination? Gestion 2000, 19(1): 109-124.

Paché, G. \& Sauvage, T. 2004. La logistique : enjeux stratégiques. Paris: Vuibert, $3^{\text {rd }}$ ed.

Paquerot, M. 1997. Stratégies d'enracinement des dirigeants, performance de la firme et structures de contrôle. In G. Charreaux (Ed.), Le gouvernement des entreprises. Corporate governance, théories et faits: 105-138. Paris: Economica.

Rokkan, A., Heide, J. \& Wathne, K. 2003. Specific investments in marketing relationships: expropriation and bonding effects. Journal of Marketing Research, 40(2): 210-224.

Roussat, C. \& Fabbe-Costes, N. 2000. Les pratiques de veille technologique en logistique: le cas des prestataires de services logistiques. Logistique \& Management, 8(2): 29-48.

Sauvage, T. 1997. Vers une conceptualisation de la relation d'agence entre les institutions du canal de distribution: application à la relation prestataire logistique-client. Thèse de doctorat en Sciences de Gestion, Université de la Méditerranée (Aix-Marseille II).

Skinner, S., Gassenheimer, J. \& Kelley, S. 1992. Cooperation in supplier-dealer relations. Journal of Retailing, 68(2): 174-193.

Stern, L. \& Reve, T. 1980. Distribution channels as political economies: a framework for comparative analysis. Journal of Marketing, 44(3): 52-64.

Tixier, D., Mathe, H. \& Colin, J. 1983. La logistique au service de l'entreprise: moyens, mécanismes et enjeux. Paris: Dunod.

Yemisi, A. 2001. The supply chain role of third-party logistics providers. International Journal of Logistics Management, 12(2): 87-102. 